\title{
The Role of Accommodation Enterprises in the Development of Sustainable Tourism
}

\author{
Muhammet Necati Çelik \\ Alanya Alaaddin Keykubat University, Antalya, Turkey \\ Aydın Çevirgen \\ Alanya Alaaddin Keykubat University, Antalya, Turkey
}

Received: 8 May 2021 Revision received: 10 June 2021 Accepted: 2 July 2021

\begin{abstract}
One of the obstacles to the success of sustainable tourism development is that the roles and responsibilities of the stakeholders in the destination are not clearly defined. This research aims to determine sustainable business practices, corporate social responsibility activities, the obstacles encountered while performing these activities, and the provided benefits within the roles and responsibilities of accommodation enterprises. The study used a phenomenology research design, a qualitative study method. A semi-structured interview form was implemented to 19 senior managers of 22 accommodation enterprises in Alanya that have environmentally friendly certificates. The results showed that the managers of the accommodation enterprises considered themselves responsible for the protection and development of the environment and that the sustainable business practices they performed were mostly ecological. It was also revealed that managers of accommodation enterprises should pay more attention to planning, which is one of the basic principles of sustainable tourism. The study's main contribution is that it discusses sustainable business practices and corporate social responsibility activities together to determine the roles of accommodation enterprises in sustainable tourism development. Besides that, it also examines the factors that prevent sustainable business practices and their benefits. Considering that few empirical studies holistically discuss the role of accommodation enterprises in the sustainable development of tourism, this study is expected to provide a significant contribution to the literature. Deficiency of planning, mainly performing ecologically sustainable business practices, and the necessity of an effective governance system are among the implications of the research.
\end{abstract}

Key Words: sustainable tourism, sustainable business practices, corporate social responsibility, accommodation enterprises, Alanya

JEL Classification: Z31, Z32

Reference: Çelik, M. N. \& Çevirgen, A. (2021). The Role of Accommodation Enterprises in the Development of Sustainable Tourism. Journal of Tourism and Services, 23(12), 181-198. doi: 10.29036/jots.v12i23.264

\section{Introduction}

Tourism covers a period in which tourists set out from where they reside to a different location until they once again return to their place or residence; in this process, tourists interact with the economic, social, cultural, and physical environment in their visited destination (Leiper, 1981). As a result of this interaction, economic contributions as well as some negative social, cultural, and physical effects may occur (Baltacı \& Çevirgen, 2020; Ribeiro, Valle \& Silva, 2013; Swarbrooke, 1999; Vodeb, Fabjan, \& Nižić, 2021). The emerging negative effects can be minimized by managing tourism activities with a sustainable 


\section{JOURNAL OF TOURISM AND SERVICES}

Issue 23, volume 12, ISSN 1804-5650 (Online)

www.jots.cz

tourism approach. In order for sustainable tourism development to be successful, local authorities and decision makers, must adopt an integrated management approach and include all stakeholders in the decision-making process (Çevirgen \& Kesgin, 2007, p.310; Ozgit \& Zhandildina, 2021). In this process, an effective governance system should be established among stakeholders (UNWTO, 2019), the areas where each stakeholder is responsible should be determined, and their roles should be specified (Dodds \& Butler, 2010). For sustainable tourism development, all sectors that can positively or negatively affect the destination and its environment, especially businesses that continue their activities in the basic areas such as accommodation, food and beverage, and transportation have important duties (Demir \& Çevirgen, 2006, p.118). All of the stakeholders in the destination have very critical responsibilities (Roxas, Rivera, \& Gutierrez, 2020), but private tourism enterprises have the greatest responsibilities of all as tourism enterprises are the real actors of the tourism industry. While the public sector designs a roadmap for tourism development by making policies and planning, the private sector is the implementer of this designed roadmap. Accommodation enterprises are one of the most important practitioners of the tourism industry and provide accommodation, catering, entertainment, etc., as well as have many responsibilities to support the development of sustainable tourism.

Accommodation enterprises interact with other stakeholders such as the local government, nongovernmental organizations, local people, universities, etc. (Kurar, 2021). While they continue their activities, they also positively or negatively affect the socio-cultural, economic, and physical environment of the region (Gavurova et al., 2021). The failure of management of the waste produced as a result of activities such as eating, drinking and entertainment, not reducing the water and electricity consumption to the optimum level, and other operations being carried out by enterprises that damage the environment, endanger both the economic continuity of the accommodation enterprises, and the quality of life of the local people. Management of accommodation enterprises within the framework of the concept of sustainable tourism is very important in terms of both the sustainability of the destination and their economic continuity.

The tourism industry is a large sector that provided direct, indirect, and induced employment to approximately 330 million people around the world in 2019 (WTTC, 2020, p.2). The overall tourism sector in Turkey provides employment for over 2 million people and the accommodation sector within it employs over 300 thousand people (OECD, 2021). In Alanya, 631 accommodation enterprises continued their activities in 2019 according to the data of the Alanya Chamber of Commerce and Industry (ACCI, 2020). According to 2019 data, Alanya is a coastal destination that hosts approximately 6.7 million tourists a year and generates $\$ 4.5$ billion in tourism (ACCI, 2020, p.46). However, the intensive tourism activities which have been carried out since the 1980s have not only brought economic gain but have also had many negative effects such as the decrease in agricultural areas and the increase in population density (Çevirgen \& Kesgin, 2007, p.314).

The main purpose of this research is to determine the role of accommodation enterprises in Alanya in sustainable tourism development. One of the important results of Dodds and Butler's (2010, p.47) study carried out to determine the situations that prevent the success of sustainable tourism policies is that the roles and areas of responsibility reported under the uncertainty factor are not clearly defined. Therefore, it is important to determine the roles and responsibilities of accommodation enterprises, which are one of the most important elements of the private sector, regarding the development of sustainable tourism. In this context, sustainable business practices, corporate social responsibility activities, the obstacles encountered while performing these activities, and the provided benefits will be examined by a qualitative approach in the research. Few studies in the literature have examined accommodation enterprises from a holistic perspective within the framework of sustainable business practices and corporate social responsibility-providing voluntary contribution to a better society and a cleaner environment; therefore, the findings obtained from this study provide in-depth information to the literature and pave the way for future studies. 


\section{JOURNAL OF TOURISM AND SERVICES}

Issue 23, volume 12, ISSN 1804-5650 (Online)

www.jots.cz

\section{Literature review}

\subsection{Sustainable tourism as a development tool}

Following the Brundtland Report published by the United Nations in 1987 and the Agenda 21 action plan put forward in 1992, sustainability and sustainable development have gained importance and become concepts for discussion over the years. The most widely accepted definition of the concept of sustainable development is "development that meets today's needs without compromising the ability of future generations to meet their own needs" which was stated in the report published by the World Commission on Environment and Development (1987, p.41). Simply, the concept of sustainable tourism can be defined as a reflection of the idea of sustainable development on the tourism sector (Weaver, 2006, p.10). According to another definition, sustainable tourism refers to "a tourism development that takes into account its current and future economic, social, and environmental impacts and is sensitive to the needs of visitors, industry, the environment, and host communities" (UNEP \& WTO, 2005, p.12). Today, the importance given to these concepts is gradually increasing. The declaration of 2017 as the "International Year of Sustainable Tourism for Development" by the United Nations created awareness all over the world and caused the organization of local, national and even international events. As a result of all these activities, the United Nations World Tourism Organization (UNTWO) emphasized in various documents that the roles of stakeholders are very important in ensuring the sustainability of these activities in destinations where tourism activities intensely take place (UNWTO, 2013; UNWTO, 2016; UNWTO, 2019).

\subsection{Stakeholder theory and governance in tourism}

All kinds of organizations, groups or individuals that enterprises interact with constitute the stakeholders of the business. Freeman (1984, p.46) defined the concept of stakeholder as any group or individual who is affected by the success of the organization's goals or influences its success. In the tourism sector, a stakeholder is anyone who is positively or negatively affected by tourism development (Minnaert, 2020, p.2). The stakeholder approach put forward by Freeman emphasizes that businesses are affected by organizations or groups they work with in their external environment and the success of the business depends on this (Freeman, 1984, p.25). Therefore, in order for sustainable tourism development to be fully successful, the stakeholders of a business or organization working together should pay attention to this issue.

Many different stakeholders are involved in the tourism sector and these stakeholders are directly and indirectly affected by tourism development (UNWTO, 2013, p.19). The literature review shows seven different types of stakeholders: local communities, public sector, private sector, universities, media organizations, non-governmental organizations, and tourists (Swarbrooke, 1999, p.85; UNWTO, 2019; Weaver \& Lawton, 2006, p.3). Attitudes of stakeholders such as business groups and local people are not always homogeneous and may differ (Hardy \& Pearson, 2018, p.255-256; UNWTO, 2019). Pjerotic (2017, p.156) mentioned that involving different stakeholders in the managerial processes of the destination contributes to the development of the destination. For this reason, establishing a system where stakeholders are in constant communication regarding sustainable tourism development will benefit all stakeholders in the destination. Brokaj (2014, p.112) examined the role of local governments in sustainable tourism development and found a lack of awareness of local governance and the implementation of this awareness in the tourism sector. An effective governance system at the local level should be established in order to eliminate such deficiencies. Today, it can be argued that the concept of governance, which is emphasized in the reports and activities of various non-governmental organizations, means "managing together" (Şanlıöz-Özgen, 2016, p.154). Governance has a participatory understanding where individuals, groups, or organizations taking part in the management process are actually expected to be included in the management process, contrary to the understanding that only one manager makes 


\section{JOURNAL OF TOURISM AND SERVICES}

Issue 23, volume 12, ISSN 1804-5650 (Online)

www.jots.cz

the decisions and manages the business, as required by the hierarchical structure accepted in the concept of management. A customized and effective governance ensures the participation of various actors in the decision-making process in tourism in a democratic process and creates a wide sense of ownership in the realization of the goals of sustainable tourism (Bramwell \& Lane, 2011, p.412). The concept of governance in tourism destinations can be defined as the realization of operations in these destinations by harmonizing the economic, socio-cultural, and natural environment, including all stakeholders in the decision-making process and effectively managing stakeholder relations (Mihalič, Šegota, Cvelbar, \& Kuščer, 2016, p.1493). It is very important to first determine who will be seen as stakeholders and then to reveal what the identified stakeholders can do to make tourism more sustainable to establish governance structures in tourism destinations (Byrd, 2007, p.7).

\subsection{The role of accommodation enterprises as a stakeholder}

As noted before, accommodation enterprises are one of the most important tourism stakeholders (UNWTO, 2019). Within the tourism sector and among other sectors, accommodation enterprises are leading private sector representatives that manage their operations within the scope of environmentally friendly management practices (Swarbrooke, 1999, p.301). According to the review of relevant literature, accommodation enterprises contribute to sustainable tourism development through sustainable business practices and corporate social responsibility activities (Legrand, Sloan, \& Chen, 2017). Enterprises that implement sustainable business practices are businesses that aim to meet the needs of the society and contribute to the well-being of all living things on earth while also providing their products and services (Bae \& Smardon, 2011, p.178). Therefore, sustainable business practices appear as production processes that consider the interests of society and all living things on earth. Sustainable business practices can be examined in ecological, economic, and social dimensions in accommodation enterprises (Legrand, Sloan, \& Chen, 2017, p.28; Raderbauer, 2011, p.18). Corporate social responsibility can be defined as a concept in which enterprises are willing to contribute to a better society and cleaner environment (European Commission, 2021; Wut, Xu, \& Wong, 2021; Lewkowicz, 2021). In this context, corporate social responsibility refers to the voluntary activities that enterprises carry out for the development of society and the environment.

Accommodation enterprises can provide various benefits such as gaining a competitive advantage, saving costs and surviving in times of crisis owing to sustainable business practices and corporate social responsibility activities (Bader, 2005, p.77; Legrand, Sloan, \& Chen, 2017, p.437; Ortizde-Mandojana \& Bansal, 2015, p.1). There are study findings indicating that sustainable business practices in hotels positively affect customer loyalty (Olya, Altinay, Farmaki, Kenebayeva, \& Gursoy, 2020, p.5). In addition, tourism businesses with corporate social responsibility strategies can earn financial rewards thanks to their contributions to help the promotion and protection of social and cultural assets and their efficient use of important resources such as water (Moneva, Bonilla-Priego, \& Ortas, 2020, p.855). However, studies have shown that some accommodation enterprises encounter obstacles such as high costs, lack of stakeholder support, lack of solidarity and cooperation, and limited interest and information while implementing sustainable business practices and performing corporate social responsibility activities (Dodds \& Butler, 2010, p.47; Farmaki, Constanti, Yiasemi, \& Karis, 2014, p.18; Legrand, Sloan, \& Chen, 2017, p.436).

\section{Methods}

\subsection{Study area and problem statement}

Located in the east of the province of Antalya, the district of Alanya hosts intensive tourism activities from April to November every year. It is in the south of Turkey on the coast of the 


\section{JOURNAL OF TOURISM AND SERVICES}

Issue 23, volume 12, ISSN 1804-5650 (Online)

www.jots.cz

Mediterranean Sea. With a population of over 300 thousand, Alanya has a climate that is hot and dry in summer and warm and rainy in winter (ACCI, 2020, p.50-62). In addition to its natural areas such as beaches, Dim Stream and Cave, and the Sapadere Canyon, it also attracts the attention of tourists with its cultural gems such as the Alanya Castle, Red Tower, and the Shipyard which has managed to survive for centuries. Alanya first started tourism activities in 1948 when the Damlataş Cave was discovered, and today it has become one of Turkey's most popular destinations (Akış, 2007, p.16). Alanya hosted approximately 6.7 million tourists in 2019 and earned 4.5 billion dollars in tourism revenue (ACCI, 2020, p.46) making it one of the most important mass tourist destinations of the Mediterranean Basin. For this reason, Alanya is a valued destination that has been examined in various research conducted by Plan Bleu which is an initiative of UNEP/MAP (United Nations Environment Programme Mediterranean Action Plan) (Spilanis, Le Tellier, \& Vayanni, 2012; Tosun \& Çalışkan, 2011). Alanya is assumed as a mature destination that faces a decline in environmental, economic, and social sustainability (Spilanis et al., 2012, p.5). That means it is at the beginning of the stagnation stage of the Tourism Area Life Cycle (Butler, 1980, p.8). Because of that, studying sustainability issues are required in mature destinations like Alanya.

Accommodation enterprises operating in Turkey are certified in two categories: those that are municipality-certified and those that are tourism business-certified. According to the ACCI 2020 data, as of 2019, a total of 631 accommodation enterprises, 348 with a municipality-certification and 283 with a tourism business-certification, are actively operating in Alanya. About 9\% of these businesses (57 accommodation enterprises) have environmentally friendly accommodation management certificates (Green Star, Travelife and Green Key) and this rate should be increased along with various policies in order to continue the tourism activities in the region (Green Key, 2021; RTMCT, 2021; Travelife, 2021).

\subsection{Research design}

Determining the role of accommodation enterprises in sustainable tourism development is aimed by the research. For this purpose, the phenomenology research design, one of the qualitative research methods, was used in the study. Phenomenology research design allows a phenomenon, which detailed information cannot be obtained about, to be examined in depth (Yıldırım \& Şimşek 2013, p.78). In the study, an interview form consisting of semi-structured questions was used to get in-depth information from senior executives in the accommodation enterprises. The study also used the sampling method of criterion sampling, a purposive sampling method. In this context, it aimed to reach senior managers who are knowledgeable (regarding the research) of accommodation enterprises that operate within the boundaries of Alanya and have at least one of the international certification systems such as Green Key or Travelife, or a national certification such as Green Star, all of which serve sustainable tourism. These managers must be familiar with all the processes in accommodation business. Therefore, interviews were conducted with senior managers such as hotel owners, general coordinators, general managers, and quality coordinators. Within the scope of the research, the snowball sampling method was also used to reach the managers because it was difficult to get an appointment for one-on-one interviews and the researcher could not manage to meet with all managers individually.

The study sought answers to the following questions:

1. What is the knowledge level of the managers about the concepts of sustainable development and sustainable tourism?

2. What are the effects of accommodation enterprises on the region where they are located?

3. What are the responsibilities of accommodation enterprises for sustainable tourism development?

4. What types of sustainable business practices are conducted in accommodation enterprises?

5. What kinds of corporate social responsibility activities are carried out in accommodation enterprises?

6. What are the benefits of and obstacles to sustainable business practices in accommodation enterprises?

\subsection{Reliability and validity}




\section{JOURNAL OF TOURISM AND SERVICES}

Issue 23, volume 12, ISSN 1804-5650 (Online)

www.jots.cz

In qualitative studies, validity and reliability are expressed not within the framework of these concepts as in quantitative studies, but within the framework of the concepts of credibility (internal validity), transferability (external validity), consistency (internal reliability) and verifiability (external reliability), which are thought to be in accordance with the nature of qualitative research (Guba, 1981, p.79-80; Yıldırım \& Şimşek, 2013, p.298-306). Therefore, reliability and validity have been tested in the study by considering these concepts.

The audio recordings obtained as a result of the interviews and the transcribed text files were kept to strengthen the credibility of the research. In addition, direct quotations regarding the codes and themes obtained as a result of the analysis were included in the findings section of the study.

Demographic data and other findings were presented in plain, detailed language. More understandable expressions of the participants were used in order to convey deep meanings resulting from the fact that the research included in-depth information to the reader effectively. Thus, the transferability of the research was supported.

To test the consistency of the research, previously encoded statements were re-encoded by two researchers. The frequency of agreement and disagreement resulting from the comparison of the encoding was shown and Miles and Huberman's (1994, p.64) reliability formula $[\mathrm{P}=$ number of agreements / (number of agreements + disagreement) $]$ was applied. As a result of the calculation, $[\mathrm{p}=60$ $/(13+60)=0.82] 82 \%$ was achieved. Miles and Huberman $(1994$, p.64) reported that a good consistency should be close to 0.80 . The fact that the rate $(82 \%)$ achieved is above the specified rate shows that the research is consistent.

The audio recordings of the interviews with the participants, the notes received, and the electronic materials obtained as a result of the coding made using the qualitative analysis program were kept and made available for review, which shows the verifiability of the research.

\subsection{Data collection and analysis}

The list of hotels with Green Star, Travelife, and Green Key certificates was obtained prior to starting the research. Only one enterprise had all these three certificates and so the research began with this enterprise. Then, with the help of interviewed business managers, other businesses were successively contacted. At the point where the answers given by the participants to the questions were thought to be repeated, the interviews were terminated considering that the data saturation had been reached.

Before conducting interviews with the managers, appointments were requested, and care was taken to ensure that the interviews were conducted in a quiet and calm environment on the day and time of the appointment to make the research efficient. The first data collection process began in July 2018 and the last interview was conducted in May 2019. Within the scope of the research, 19 participants representing 22 accommodation enterprises were interviewed face-to-face. Before the interviews, the participants' consent was obtained and the interviews were recorded. Of the participants, four did not accept their interviews to be recorded and they were interviewed using a written form via the computer. The audio recordings of the other 15 participants were listened to in detail and transcribed. The interviews lasted between 15 to 70 minutes.

The first step in analyzing the data was transcribing the audio recordings obtained from the interviews. In the second stage, all of the texts transcribed were read, prepared and arranged for the analysis. During this editing, statements which were biased, likely to cause misunderstanding were reviewed. In addition, expressions of the participants were carefully arranged without moving away from their authenticity. In the third stage, the data were transferred to the MAXQDA qualitative analysis program, and the coding and theming process began. Using the specific software made the coding and theming performed in the data analysis process easier and more efficient. After the coding and theming process was completed, the codes and the themes created were reviewed for the second time. 


\section{JOURNAL OF TOURISM AND SERVICES}

Issue 23, volume 12, ISSN 1804-5650 (Online)

www.jots.cz

Compatibility of the themes with the literature was checked and similar and different results were discussed.

\section{Results}

The senior managers interviewed within the scope of the research were coded as Participant 1 , Participant 2, etc. The data of the participants and the characteristics of the accommodation enterprises they represent are shown in Table 1.

Table 1. Characteristics of the participants and the enterprises

\begin{tabular}{|c|c|c|c|c|c|c|c|}
\hline $\begin{array}{l}\text { Participants } \\
\text { (P) }\end{array}$ & Position & Gender & Age & Educational level & $\begin{array}{c}\text { Sectoral/ } \\
\text { Managerial } \\
\text { Experience } \\
\text { (Year) }\end{array}$ & $\begin{array}{l}\text { Accommodation } \\
\text { Enterprise Type }\end{array}$ & $\begin{array}{l}\text { Certificates } \\
\text { Obtained }\end{array}$ \\
\hline P1 & GM & Female & 39 & Bachelor's degree & $24 / 15$ & $4 *$ hotel & GS, GK, T \\
\hline $\mathrm{P} 2$ & GM & Male & 50 & Bachelor's degree & $27 / 21$ & $5^{*}$ hotel & GS \\
\hline P3 & GM & Female & 37 & Bachelor's degree & $15 / 10$ & $5 *$ hotel & $\mathrm{T}$ \\
\hline $\mathrm{P} 4$ & QC & Female & 40 & Bachelor's degree & $11 / 9$ & $5^{*}$ hotel & GS, T \\
\hline P5 & GC & Male & 40 & Bachelor's degree & $18 / 15$ & $5 *$ hotel & GS, T \\
\hline P6 & QC & Female & 29 & Master's degree & $6 / 3$ & $5^{*}$ hotel & GS, T \\
\hline P7 & GC & Male & 49 & Bachelor's degree & $33 / 23$ & $5 *$ two hotels & GS \\
\hline P8 & $\mathrm{HO}$ & Male & 29 & Bachelor's degree & $10 / 1$ & $5 *$ hotel & GS \\
\hline P9 & GM & Male & 36 & $\begin{array}{l}\text { High school and } \\
\text { lower }\end{array}$ & $18 / 9$ & Apart hotel & $\mathrm{T}$ \\
\hline P10 & $\mathrm{HO}$ & Male & 34 & Bachelor's degree & $16 / 16$ & Apart hotel & GS \\
\hline P11 & GM & Male & 53 & Bachelor's degree & $35 / 20$ & $4 *$ hotel & GS \\
\hline P12 & GM & Male & 43 & Bachelor's degree & $22 / 17$ & $5 *$ hotel & GS \\
\hline P13 & GM & Male & 41 & $\begin{array}{l}\text { High school and } \\
\text { lower }\end{array}$ & $25 / 16$ & $\begin{array}{c}5 * \text { and } 4 * \\
\text { hotel }\end{array}$ & GS, T \\
\hline P14 & GM & Male & 48 & $\begin{array}{l}\text { High school and } \\
\text { lower }\end{array}$ & $29 / 24$ & $\begin{array}{c}\text { Municipality } \\
\text { certified hotel }\end{array}$ & $\mathrm{T}$ \\
\hline P15 & GM & Male & 56 & Bachelor's degree & $32 / 28$ & $5^{*}$ hotel & GS \\
\hline P16 & GM & Male & 53 & Bachelor's degree & $35 / 29$ & $4 *$ hotel & GS \\
\hline P17 & GM & Male & 40 & Master's degree & $20 / 14$ & $\begin{array}{l}5 * \text { and } 4 * \\
\text { hotel }\end{array}$ & GS \\
\hline P18 & GM & Male & 54 & Bachelor's degree & $35 / 21$ & $5^{*}$ hotel & GS \\
\hline P19 & VGM & Female & 36 & Bachelor's degree & $18 / 15$ & $4 *$ hotel & GS \\
\hline \multicolumn{8}{|c|}{$\begin{array}{l}\text { Shortcuts: } \\
\text { HO: Hotel Owner GM: General Manager GC: General Coordinator QC: Quality Coordinator VGM: Vice General Manager } \\
\text { GS: Green Star T: Travelife GK: Green Key }\end{array}$} \\
\hline
\end{tabular}

Source: developed by the authors.

The study data were collected from 19 managers. Of the participants interviewed, 12 were general managers, 2 were hotel owners, 2 were general coordinators, 2 were quality coordinators, and 1 was an assistant general manager. Some participants were responsible for more than one hotel; therefore, 19 managers represented 22 certified accommodation enterprises. In addition, the managers had an average of 23 years of experience in the sector and 16 years of managerial experience, which was very important in terms of revealing their experiences gained over the years as in-depth information. The findings obtained are presented below in tables showing the answers to the research questions noted in the methodology section of the study. In addition, the "(P...)" in the tables at the end of the statements indicate number of the participant whose statements were noted.

Table 2 shows that the answers given to the question asking the participants about the concepts of sustainable development and sustainable tourism have been placed under seven headings. One of the most striking findings among these headings is that the concept of planned and controlled development has rarely been mentioned. Another important finding is that the participants mainly talked about protecting and improving the environment (f: 29), continuity and permanence of activities (f: 13), and 


\section{JOURNAL OF TOURISM AND SERVICES}

Issue 23, volume 12, ISSN 1804-5650 (Online)

www.jots.cz

quality (f: 10). In addition, the topic quality was defined with two codes: innovativeness (f: 6 ) and personnel quality and training (f: 4); the topic contribution to the regional economy was defined with two codes: employment (f: 6 ) and efficient use of resources (f: 1 ).

Table 2. Knowledge level of the managers on the concepts of sustainable development and sustainable tourism

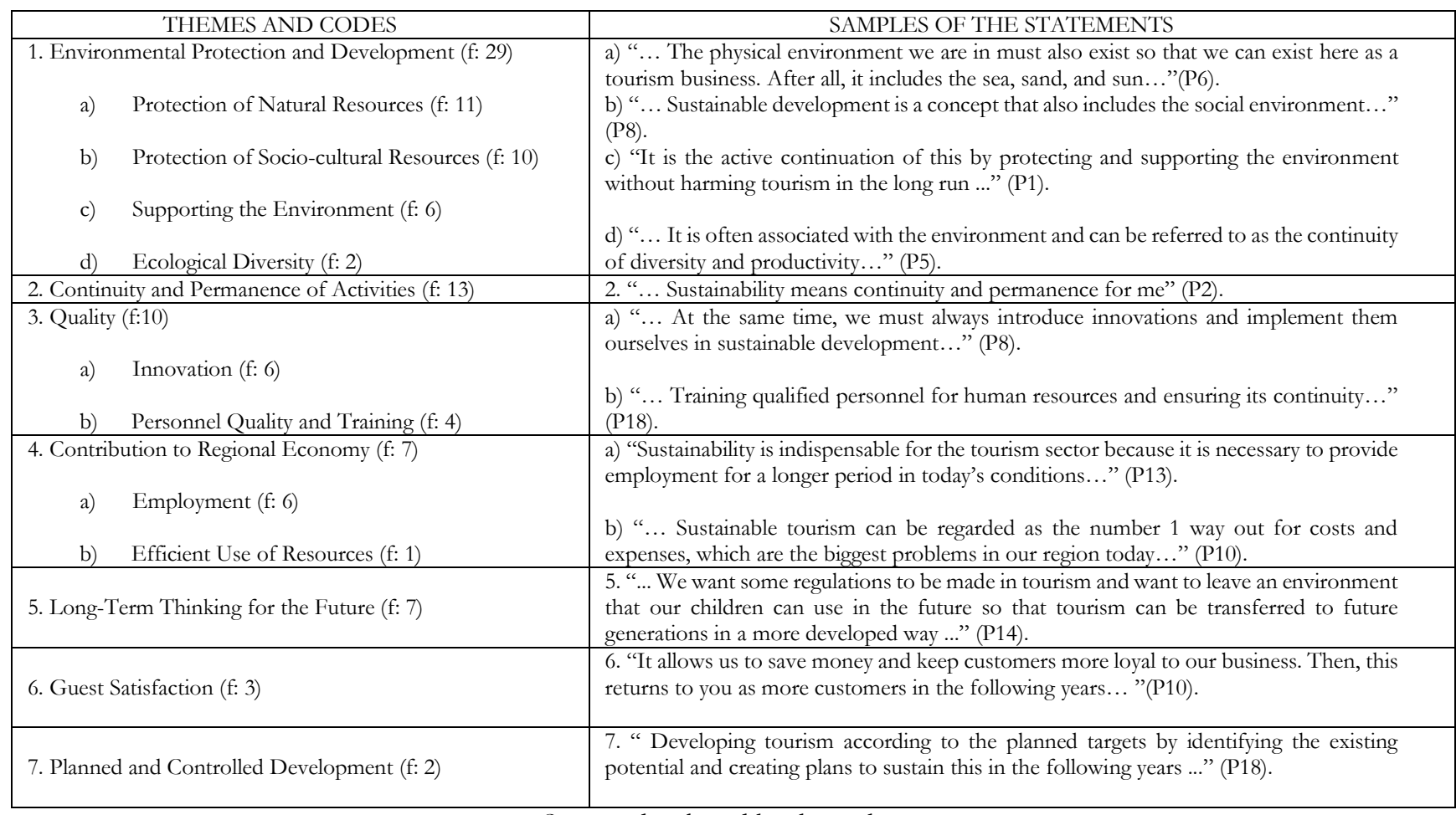

Source: developed by the authors.

As Table 3 shows, the answers given to the question asking the participants about their opinions regarding the effects of accommodation enterprises on the region were grouped in three main categories. These categories are: economic (f: 56), physical (f: 15), and socio-cultural effects (f: 14). These categories were also grouped under two headings as positive and negative effects. One of the most important findings about the effects of accommodation enterprises on the region is that the participants emphasized that these businesses had a positive role in terms of regional development (f: 12 ) and employment opportunities (f: 11). They also said that accommodation enterprises contributed economically to other sectors (f: 7). In addition, another important finding is that these enterprises predominantly negatively affect the region in physical terms and positively in socio-cultural terms.

Table 4 shows that the answers given to the question about the responsibilities of the accommodation enterprises directed to the participants are grouped under six headings. One of the important findings on this subject is that the participants who emphasized accommodation enterprises were highly responsible for protecting and improving the environment (f: 28$)$. In addition, the participants stated that accommodation enterprises had responsibilities in issues such as quality service and guest satisfaction (f: 13), continuation of economic activities (f: 6), and personnel (f: 4).

Table 5 shows that the answers given to the question about the corporate social responsibility activities of the participants in their own accommodation enterprises were grouped under four categories. These categories were: activities to support events in the region (f: 11), activities to support nature (f: 9), activities to support education (f: 9 ), and activities to support community (f: 6 ). In addition, quotations on all categories were included in the table. 
Table 3. Opinions of the managers of the accommodation enterprises on the impacts of the region

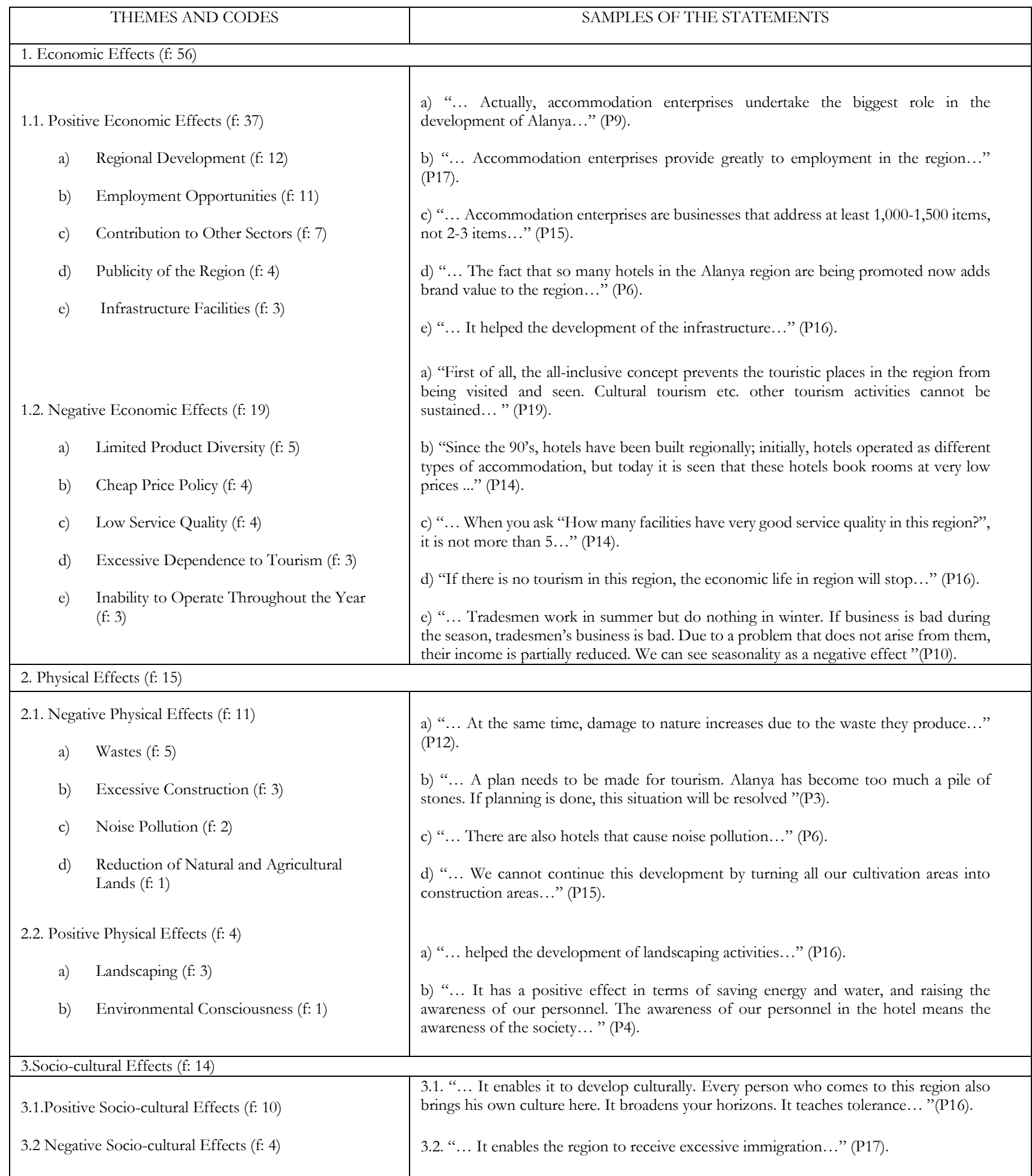

Source: developed by the authors. 
www.jots.cz

Table 4. Opinions of the managers of accommodation enterprises on their responsibilities

\begin{tabular}{|c|c|}
\hline THEMES AND CODES & SAMPLES OF THE STATEMENTS \\
\hline 1. Environmental Protection and Development (f: 28) & $\begin{array}{l}\text { a) "... Of course, we, as a facility, have a responsibility to nature and the environment } \\
\text {... (P7). }\end{array}$ \\
\hline a) Natural Environment (f: 11) & $\begin{array}{l}\text { b) "... From the history of Alanya, to local food and culture, they need to show these } \\
\text { to their guests..." (P9) }\end{array}$ \\
\hline b) Socio-cultural Environment (f: 7) & c) "... Even the fact that the facility minimizes the damage to the environment by \\
\hline c) Energy Saving (f: 5) & $\begin{array}{l}\text { considering energy saving shows its sensitivity. The fact that all the hotels in the Alanya } \\
\text { region are doing this will take Alanya to a very different point..." (P6). }\end{array}$ \\
\hline Waste Management (f: 5) & $\begin{array}{l}\text { d) “... Some waste occurs in the facilities, we need to deliver this waste to waste } \\
\text { collection areas in a controlled manner..." (P8). }\end{array}$ \\
\hline 2. Quality Service and Guest Satisfaction (f: 13) & $\begin{array}{l}\text { 2. “... We need to manage the activities that will please the guests in a quality } \\
\text { manner..." (P19). }\end{array}$ \\
\hline $\begin{array}{l}\text { 3. Sustaining Economic Activities (f: } 6 \text { ) } \\
\text { a) Innovation (f: } 4 \text { ) }\end{array}$ & $\begin{array}{l}\text { a) "... Accommodation enterprises should follow world trends and be innovative" } \\
\text { (P10). }\end{array}$ \\
\hline b) Local Employment (f: 2) & $\begin{array}{l}\text { b) "... I prefer the people who work for my business to be the local people living here, } \\
\text { which is a social responsibility for the businesses..." (P2). }\end{array}$ \\
\hline 4. Personnel (f:4) & $\begin{array}{l}\text { 4. “... First of all, accommodation enterprises should provide motivation for their } \\
\text { personnel to do this job as a profession, create a budget, and provide training..." (P17). }\end{array}$ \\
\hline 5. Publicity of the Region (f:3) & $\begin{array}{l}\text { 5. "... Then comes what the hotel has to offer about Alanya. From the history of } \\
\text { Alanya to local food and culture, they need to show these to their guests...." (P9) }\end{array}$ \\
\hline 6. Legal Responsibility (f: 2) & $\begin{array}{l}\text { 6. "Accommodation enterprises, first of all, have to follow the legislation. In particular, } \\
\text { environmental legislation is constantly updated. We have to follow this constantly... } \\
\text { "(P4). }\end{array}$ \\
\hline
\end{tabular}

Source: developed by the authors.

Table 5. Corporate social responsibility activities of accommodation enterprises

\begin{tabular}{|c|c|}
\hline THEMES AND CODES & SAMPLES OF THE STATEMENTS \\
\hline 1. Activities to Support Events in the Region (f: 11) & 1. “... We sponsored a bicycle race held in Alanya in the past years..." (P2). \\
\hline 2. Activities to Support Nature (f: 9) & $\begin{array}{l}\text { 2. " } \ldots \text { We support activities such as environmental cleaning and tree planting carried } \\
\text { out by various non-governmental organizations..." (P10). }\end{array}$ \\
\hline 3. Activities to Support Education (f: 9) & $\begin{array}{l}\text { 3. “... We provide scholarship opportunities to students. We make donations to } \\
\text { various educational institutions..."(P19). }\end{array}$ \\
\hline 4. Activities to Support Community (f: 6) & $\begin{array}{l}\text { 4. "... We received a blue flag for our beach and we serve publicly. People in this region } \\
\text { can benefit from our beach even if they do not stay at our hotel...." (P6). }\end{array}$ \\
\hline
\end{tabular}

Source: developed by the authors.

Table 6. Sustainable business practices of accommodation enterprises

\begin{tabular}{|c|c|}
\hline THEMES AND CODES & SAMPLES OF THE STATEMENTS \\
\hline 1. Ecological Practices (f: 30) & $\begin{array}{l}\text { a)“... For example, we are very careful about sorting waste. We are very careful about } \\
\text { sending hazardous wastes separately...”(P4). }\end{array}$ \\
\hline a) Waste Management (f: 13) & b)“... Environmentally, I have had cat houses built for the cats to live in the hotel \\
\hline b) Supporting Natural Life (f: 6) & garden. I have had 10 bird houses built and hung them on trees... ”(P2). \\
\hline c) Environment Friendly Purchasing Policy (f: 5) & $\begin{array}{l}\text { c) “... Apart from that, we try to use more environmentally friendly materials..." } \\
\text { (P10). }\end{array}$ \\
\hline d) Renewable Energy (f: 4) & d)“...We meet our hot water needs by using solar energy systems...” (P19). \\
\hline Reduction of Chemical Consumption (f: 2) & e) "...We are trying to reduce the use of chemicals..." (P6). \\
\hline
\end{tabular}




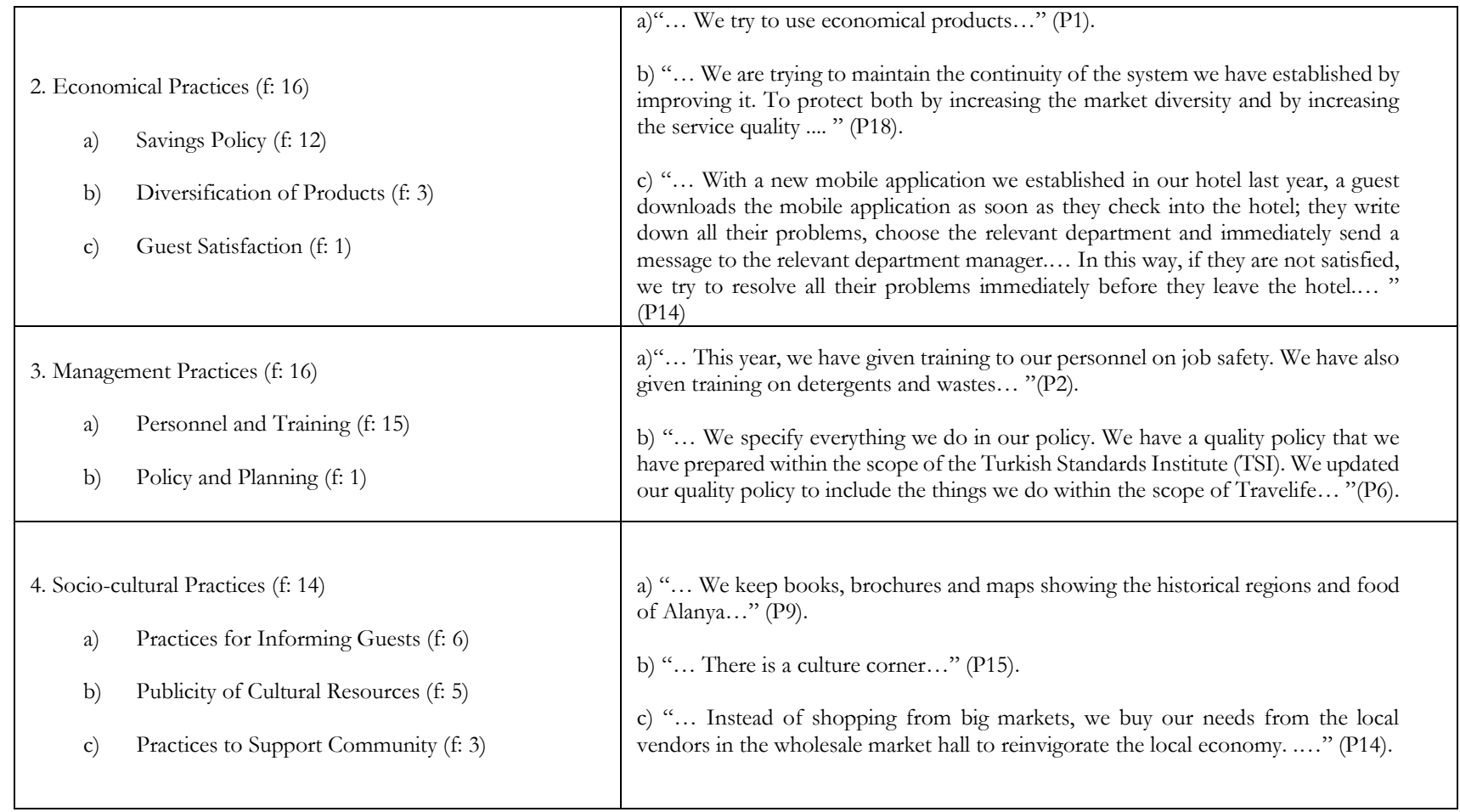

Source: developed by the authors.

As Table 6 shows, the answers given to the question about the sustainable business practices of the participants in their own accommodation enterprises are grouped under four categories. One of the most important findings about sustainable business practices of accommodation enterprises was that they were predominantly ecological practices (f: 30). Other practices the participants emphasized were economic (f: 16), managerial (f: 16), and socio-cultural practices (f: 14). Another finding was that the practices of the participants in policy and planning (f: 1$)$ were insufficient.

Table 7 shows the obstacles that the participants faced while performing sustainable business practices and the benefits of these practices that they put into practice. Participants emphasized that these practices provide the most economic benefits (f: 31), and secondarily, they provide benefits to the environment (f: 8). In addition, the obstacles encountered while these practices are being carried out were: the personnel problem (f: 9), physical problems and opportunities (f: 8), unconsciousness and indifference (f: 7), creation of costs (f: 5 ), seasonality (f: 3 ), too many procedures (f: 3 ), and failure in institutionalization (f: 1).

Table 7. Benefits of sustainable business practices and obstacles encountered in accommodation enterprises

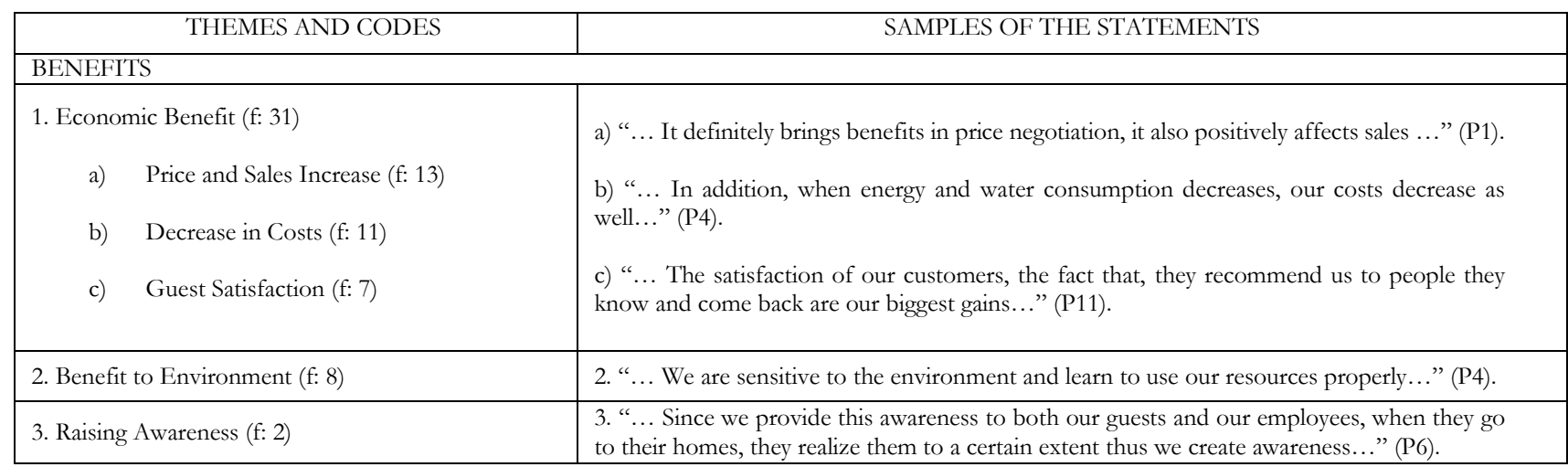




\begin{tabular}{|c|c|}
\hline 4. Making You Feel Good (f: 2) & 4. "... Later on it gives you peace and happiness you as you do less harm to nature ..." (P12). \\
\hline 5. Contribution to the Image of the Region (f: 1 ) & 5. "... It is possible that the image of the region will be positively affected...” (P15). \\
\hline \multicolumn{2}{|l|}{ OBSTACLES } \\
\hline 1. Personnel Problem (f: 9) & $\begin{array}{l}\text { 1. "... The fact that the workforce does not adopt the sector and that the sector is seasonal..." } \\
\text { (P15). }\end{array}$ \\
\hline 2. Physical Problems and Facilities (f: 8) & $\begin{array}{l}\text { 2. “... Our current physical conditions pose problem for us as we are an inner city hotel..." } \\
\text { (P8). }\end{array}$ \\
\hline 3. Unconsciousness and Indifference (f: 7) & 3. "... The failure of local governments to act with this awareness...” (P15) \\
\hline 4. Creation of Costs (f: 5) & 4. "... It requires costs to maintain these activities and obtain the documents..." (P6). \\
\hline 5. Seasonality (f: 3) & $\begin{array}{l}\text { 5. "... The fact that tourism activities cannot be spread over } 12 \text { months and that they are } \\
\text { seasonal..." (P18). }\end{array}$ \\
\hline 6. Lots of Procedures (f: 3) & $\begin{array}{l}\text { 6. “... There are many documents that need to be put into legal practice... you have difficulty } \\
\text { with some things..." (P1). }\end{array}$ \\
\hline 7. Failure in Institutionalization (f: 1 ) & $\begin{array}{l}\text { 7. "... Since there are boss enterprises and there is no institutionalization, you can meet } \\
\text { different difficulties by learning different things in every business you go to..." (P16). }\end{array}$ \\
\hline
\end{tabular}

Source: developed by the authors.

In summary, the findings of the research are grouped under seven headings. These headings are presented as the knowledge level of the accommodation enterprise managers about the concepts of sustainable development and sustainable tourism, their thoughts on the effects of the accommodation enterprise on the region, their thoughts on the responsibilities of the accommodation enterprises, their corporate social responsibility activities, the sustainable business practices they carry out, the benefits of sustainable business practices, and the obstacles encountered.

\section{Discussion and conclusion}

Today, many destinations where intense tourism activities are performed have entered an irreversible impasse and are looking for a solution because they do not adopt a sustainable tourism approach against the negative effects of tourism. Investigating this issue in detail before the existing resources are lost, revealing the sustainable business practices and social responsibility activities carried out by the accommodation enterprises in their operations in order to support the sustainability of the destination, and encouraging other accommodation enterprises in this regard are extremely important.

As the first result of this study, the managers of the accommodation enterprises associate the concept of sustainable tourism with the concepts of environmental awareness, continuity of activities, and quality service. Accordingly, it can be argued that the level of knowledge of the managers regarding the concepts of sustainable tourism is high. On the contrary, Musavengane (2019) mentioned that hotel owners have less awareness about environmental, social, and economic aspects of sustainable tourism in the results of his research. However, the fact that only two participants mentioned the issue of including tourism within the scope of planning and its controlled development, which is among the basic principles of sustainable tourism, shows that these issues are not sufficiently taken into account in the sustainable development of tourism and remain in the background. These results are an answer to the first question of the research.

Regarding the second question of the research, which was concerning the effects of accommodation enterprises on the region, the managers mostly focused on the positive economic effects such as creating regional development, employment opportunities, and contributing to other sectors. In addition, it should be noted that they also mentioned some negative economic effects such as limited product variety, low service quality, cheap pricing policy, seasonality, and excessive dependence on 


\section{JOURNAL OF TOURISM AND SERVICES}

Issue 23, volume 12, ISSN 1804-5650 (Online)

www.jots.cz

tourism. These effects obtained from the present research are mostly similar to findings of the research performed by Prayag, Dookhony-Ramphul, and Maryeven (2010) in Maritius and Guden, Girgen, Saner, and Yesilpinar (2021) in Cyprus. Steps such as diversification of products, determination of quality standards, and review of price policy can be taken by accommodation enterprises in Alanya by turning to different types of tourism to eliminate the aforementioned negative effects. Determining the products that can be sold not only in the summer but also in other seasons can prevent seasonality, which has a negative effect. In addition to these, there are statements noting that accommodation enterprises cause negative physical problems such as waste, excessive construction, noise pollution, and the reduction of natural and agricultural lands. Accordingly, policies that encourage enterprises in waste management should be determined by local governments and various measures should be taken against excessive construction and noise pollution. In the context of its socio-cultural effects, the positive effects of tourism are emphasized more. Although these results are welcomed in the context of the sustainability of tourism, it is necessary to carry out studies on eliminating the existing negativities and increasing the positive effects.

Another result of the research concerns the responsibilities of accommodation enterprises in sustainable tourism development. The managers feel responsible for protecting and improving the environment, providing quality service and establishing guest satisfaction, maintaining economic activities, responsibilities toward personnel, publicity of the region, and legal responsibilities. These results answered the third research question in the study.

The managers feel most responsible for protecting and developing the environment, which brings to mind the question of whether accommodation enterprises are carrying out any sustainable business practice in this regard. The fact that the sustainable business practices of the participants in their accommodation enterprises are gathered mostly under ecological practices is an indication that the managers behave responsibly. The managers involved in the study also talked about their economic, socio-cultural, and administrative practices as well as their ecological practices. The study found that ecological practices are emphasized more which is alike with the research findings of Khatter, McGrath, Pyke, White, and Lockstone-Binney (2019), and waste management, a practice involved in the issue in question, is more prominent. In addition, the managers emphasized saving policies among economical practices, informing guests among socio-cultural practices, and personnel and training issues among management practices. These results provided answers to the fourth question of the research. More detailed information on this subject can be found in the findings section. Legal regulations to be introduced by the public sector and various environmentally sensitive certification systems can play an important role in the further dissemination of the applications of accommodation enterprises in these issues. The results of the study carried out by Raderbauer (2011) support this opinion.

When the accommodation enterprises are evaluated in terms of their practices within the scope of corporate social responsibility, they are engaged in activities supporting activities in the region, protecting nature, supporting education, and society. Thus, the fifth question of the research was answered. This result is similar to the environmental problems and community participation issues in the study conducted by Bissoon (2018) on corporate social responsibility in four- and five-star group hotels in Mauritius.

Considering the evaluations of the participants on the benefits of sustainable business practices in accommodation enterprises, they provide benefits in economic and environmental terms, awareness raising, making people feel good, and contributing to the image of the region. In the economic benefit, which is more emphasized compared to other benefits, the issues of increasing prices and sales, decreasing costs, and guest satisfaction seem to be important. Therefore, it can be concluded that sustainable business practices can enable accommodation enterprises to gain a competitive advantage in marketing, reduce their costs in various expenditures, and increase the demand for the business as a result of guest satisfaction. In addition, since few studies in the literature discussed the benefits of sustainable 


\section{JOURNAL OF TOURISM AND SERVICES}

Issue 23, volume 12, ISSN 1804-5650 (Online)

www.jots.cz

business practices (Zaiton, Syamsul, Kasimu \& Hassan, 2016), these findings obtained from the present research can significantly contribute to the literature.

Based on the participating managers' statements regarding the obstacles they encounter while performing sustainable business practices in accommodation enterprises, these obstacles in order of importance were personnel problems, physical problems and facilities, unconsciousness and indifference, costs, seasonality, too many procedures, and failure in institutionalization. Thus, the last research question of the research was answered. These results are similar to the topics such as lack of environmental knowledge and skills, lack of specialized personnel, and high costs discussed in Sucheran's study which was conducted on 60 hotels and that examined obstacles to environmental practices (Sucheran, 2018, p.1356-1357). In addition, the results of another research show similarities about the obstacle of seasonality with the findings of present research (Guden et al., 2021).

In general, the managers of the accommodation enterprises involved in the research in the Alanya region have high sensitivity to the environment, and they make significant contributions to the sustainable development of tourism thanks to their responsibilities and practices. One of the most important contributions of this research is that it discusses sustainable business practices and corporate social responsibility activities together in order to determine the roles of accommodation enterprises in sustainable tourism development. The study not only addresses these two concepts, but it also examines the factors that prevent sustainable business practices and their benefits. Given that there are few empirical studies that holistically discuss the role of accommodation enterprises in the sustainable development of tourism, this study is expected to provide significant contribution to the literature. The study can also set a good example for other mature destinations these face a decline in environmental, economic and social sustainability.

Some practical implications can also be made in this study. One of them is that managers of accommodation enterprises should pay more attention to planning in their operations. In addition, it should be noted that the responsibilities are not limited to the accommodation sector in ensuring a sustainable tourism development in tourism destinations. In this context, a "Destination Management Organization" should be established to determine the roles of all stakeholders in the destination and to ensure an effective governance system.

The results of this study are limited to a certain number of accommodation enterprises operating in Alanya. Also, the research was carried out only in environmentally friendly accommodation enterprises that have Travelife, Green Key, or Green Star certificates. Finally, it should not be forgotten that the findings obtained within the scope of the research correspond to the time it was conducted.

Based on the findings obtained from the research, the subject of planning in sustainable tourism development, which emerged as a deficiency as a result of the research, should be examined in more detail in future studies. The dimensions determined for the research topics and the findings obtained from the study should be tested with quantitative studies carried out with larger samples. In addition, similar empirical studies should be conducted in the future with other destination stakeholders and a large number of other accommodation enterprises that do not have environmentally sensitive certificates. As a result of this, their roles in the sustainable development of tourism can also be determined and they can be asked to fulfill their responsibilities for the development of sustainable tourism. Finally, conducting further studies similar to this research in different regions and cultures will provide different results and contribute to the literature.

\section{Acknowledgements}

This article is based on a master's thesis produced by Muhammet Necati Çelik under the direction of Aydin Çevirgen at Alanya Alaaddin Keykubat University in Antalya, Turkey. 


\section{JOURNAL OF TOURISM AND SERVICES}

Issue 23, volume 12, ISSN 1804-5650 (Online)

www.jots.cz

\section{References}

1. ACCI (Alanya Chamber of Commerce and Industry). (2020). Alanya Ekonomik Raporu 2019 [Alanya Economic Report 2019]. Antalya: Alanya Chamber of Commerce and Industry. Retrieved from https://www.altso.org.tr/yayinlarimiz/alanya-ekonomik-rapor/alanya-ekonomik-rapor$2019 /$

2. Akış, A. (2007). Alanya'da turizm ve turizmin alanya ekonomisine etkisi [Tourism and its impact on economy in Alanya]. Selçuk. Üniversitesi Sosyal Bilimler Enstitüsü Dergisi [Journal of Social Science Institute in Selcuk University], 17, 15-32. Retrieved from http://dergisosyalbil.selcuk.edu.tr/susbed/article/view/468/450

3. Bader, E. E. (2005). Sustainable hotel business practices. Journal of Retail \& Leisure Property, 5(1), 70-77. doi: 10.1057 / palgrave.rlp.5090008

4. Bae, H., \& Smardon, R. S. (2011). Indicators of Sustainable Business Practices. In E. Broniewicz, Environmental Management in Practice (pp. 177-206). Rijeka: INTECHWEB.ORG.

5. Baltac1, F., \& Çevirgen, A. (2020). The impacts of second home tourism on socio-cultural and economic life: the residents' perspectives. Journal of the Geographical Institute "Jovan Cvijic" SASA, 70(3), 273-288. doi: 10.2298/IJGI2003273B

6. Bissoon, O. (2018). Coporate social responsibility in Maritius: an analysis of annual reports of multinational hotel groups. Asian Journal of Sustainability and Social Responsibility, 3(2), 1-19. doi: 10.1186/s41180-017-0017-4

7. Bramwell, B., \& Lane, B. (2011). Critical research on the governance of tourism and sustainability. Journal of Sustainable Tourism, 19(4-5), 411-421. doi: 10.1080/09669582.2011.580586

8. Brokaj, R. (2014). Local government's role in the sustainable tourism development of a destination. European Scientific Journal, 10(31), 103-117. Retrieved from https://eujournal.org/index.php/esj/article/view/4571

9. Butler, R. W. (1980). The concept of a tourist area cycle of evolution implications for management of resources. Canadian Geographer, 24(1), 5-12. doi: 10.1111/j.1541-0064.1980.tb00970.x

10. Byrd, E. T. (2007). Stakeholders in sustainable tourism development and their roles: applying stakeholder theory to sustainable tourism development. Tourism Review, 62(2), 6-13. doi: 10.1108/16605370780000309

11. Çevirgen, A., \& Kesgin, M. (2007). Local authorities' and NGOs' perceptions of tourism development and urbanization in Alanya. Tourism: An International Interdisciplinary Journal, 55, 309322. Retrieved from https://hrcak.srce.hr/24651

12. Demir, C., \& Çevirgen, A. (2006). Turiz̧m ve Çevre Yönetimi: Sürdürülebilir Gelișe Yaklaşım [Tourism and Environmental Management: Sustainable Development Approach]. Ankara: Nobel Academic Publishing.

13. Dodds, R., \& Butler, R. (2010). Barriers to implementing sustainable tourism policy in mass tourism destinations. Tourismos: An International Multidisciplinary Journal of Tourism, 5(1), 35-53. Retrieved from https://mpra.ub.uni-muenchen.de/25162/

14. European Commission (2021). Corporate social responsibility \& Responsible business conduct. European Commission. Retrieved June 9, 2021, from https://ec.europa.eu/growth/industry/sustainability/corporate-social-responsibility_en

15. Farmaki, A., Constanti, P., Yiasemi, I., \& Karis, P. (2014). Responsible tourism in Cyprus: the rhetoric and the reality. Worldwide Hospitality and Tourism Themes, 6(1), 10-26. doi: 10.1108/WHATT-10-2013-0041

16. Freeman, R. (1984). Strategic Management: A Stakeholder Approach. Boston: Pitman Publishing Inc.

17. Gavurova, B., Belas, J., Valaskova, K., Rigelsky, M., \& Ivankova, V. (2021). Relations between infrastructure innovations and tourism spending in developed countries: a macroeconomic 


\section{JOURNAL OF TOURISM AND SERVICES}

Issue 23, volume 12, ISSN 1804-5650 (Online)

www.jots.cz

perspective. Technological and Economic Development of Economy, 27(5), 1072-1094. https://doi.org/10.3846/tede.2021.15361

18. Green Key (2021). Green Key Official Website. Retrieved January 23, 2021, from https://www.greenkey.global/

19. Guba, E. G. (1981). Criteria for assessing the trustworthiness of naturalistic inquiries. Educational Communication and Technology, 29(2), 75-91. Retrieved from https://link.springer.com/article/10.1007/BF02766777

20. Guden, N., Girgen, M. U., Saner, T., \& Yesilpinar, E. (2021). Barriers to sustainable tourism for small hotels in small island developing states and some suggested remedies. Worldwide Hospitality and Tourism Themes, Ahead of print(Ahead of print), 1-12. doi: 10.1108/WHATT-02-2021-0032

21. Hardy, A., \& Pearson, L. J. (2018). Examining stakeholder group specificity: An innovative sustainable tourism approach. Journal of Destination Marketing \& Management, (8), 247-258. doi: 10.1016/j.jdmm.2017.05.001

22. Khatter, A., McGrath, M., Pyke, J., White, L., \& Lockstone-Binney, L. (2019). Analysis of hotels' environmentally sustainable policies and practices sustainability and corporate social responsibility in hospitality and tourism. International Journal of Contemporary Hospitality Management, 31(6), 2394-2410. doi: 10.1108/IJCHM-08-2018-0670

23. Kurar, I. (2021). Research on the determination of recreational experience preferences, expectations, and satisfaction levels of local people. International Journal of Entrepreneurial Knowledge, 9(1), 41-66. doi: 10.37335/ijek.v9i1.122

24. Legrand, W., Sloan, P., \& Chen, J. S. (2017). Sustainability in the Hospitality Industry Principles of Sustainable Operations. Oxon: Routledge.

25. Leiper, N. (1981). Towards a cohesive curriculum in tourism the case for a distinct discipline. Annals of Tourism Research, 69-84. doi: 10.1016/0160-7383(81)90068-2

26. Lewkowicz, R. (2021). Informal practices in illicit border-regimes: The economy of legal and fake travel documents sustaining the EU asylum system. Migration Letters, 18(2), 177-188. doi:10.33182/ml.v18i2.1189

27. Mihalič, T., Šegota, T., Cvelbar, L. K., \& Kuščer, K. (2016). The influence of the political environment and destination governance on sustainable tourism development: a study of Bled, Slovenia. Journal of Sustainable Tourism, 24(11), 1489-1505. doi: 10.1080/09669582.2015.1134557

28. Miles, M. B., \& Huberman, A. M. (1994). An Expanded Sourcebook Qualitative Data Analysis. Thousand Oaks: SAGE Publications.

29. Minnaert, L. (2020). Stakeholder stories: Exploring social tourism networks. Annals of Tourism Research, (83), 1-12. doi: 10.1016/j.annals.2020.102979

30. Moneva, J. M., Bonilla-Priego, M. J., \& Ortas, E. (2020). Corporate social responsibility and organisational performance in the tourism sector. Journal of Sustainable Tourism, 28(6), 853-972. doi: 10.1080/09669582.2019.1707838

31. Musavengane, R. (2019). Small hotels and responsible tourism practice: Hoteliers' perspectives. Journal of Cleaner Production, 220, 786-799. doi: 10.1016/j.jclepro.2019.02.143

32. OECD (Organization for Economic Co-operation and Development) (2021). OECD Statistics. Retrieved January 23, 2021, from https://stats.oecd.org/Index.aspx?DataSetCode=TOURISM_ENTR_EMPL

33. Olya, H., Altinay, L., Farmaki, A., Kenebayeva, A., \& Gursoy, D. (2020). Hotels' sustainability practices and guests' familiarity, attitudes and behaviours. Journal of Sustainable Tourism, 1-19. doi: 10.1080/09669582.2020.1775622

34. Ortiz-de-Mandojana, N., \& Bansal, P. (2015). Long term benefits of organizational resilience through sustainable business practices. Strategic Management Journal, 37. doi: 10.1002/smj.2410

35. Ozgit, H., \& Zhandildina, D. (2021). Investigating stakeholder awareness of the sustainable development goals and tourism stakeholder collaboration: the case of North Cyprus. Worldwide 


\section{JOURNAL OF TOURISM AND SERVICES}

Issue 23, volume 12, ISSN 1804-5650 (Online)

www.jots.cz

Hospitality and Tourism Themes, Ahead of print(Ahead of print), 1-12. doi: 10.1108/WHATT-022021-0027

36. Pjerotic, L. (2017). Stakeholder cooperation in implementation of the sustainable development concept: Montenegrin tourist destinations. Journal of International Studies, 10(2), 148-157. doi: 10.14254/2071-8330.2017/10-2/11

37. Prayag, G., Dookhony-Ramphul, K., \& Maryeven, M. (2010) Hotel development and tourism impacts in Mauritius: Hoteliers' perspectives on sustainable tourism. Development Southern Africa, 27(5), 697-712. doi: 10.1080/0376835X.2010.522832

38. Raderbauer, M. (2011). The importance of sustainable business practices in Viennese accommodation industry. (Master's Thesis) Exeter, United Kingdom: University of Exeter. Retrieved from https://www.wien.gv.at/umweltschutz/nachhaltigkeit/pdf/raderbauer.pdf

39. Ribeiro, M. A., Valle, P. O., \& Silva, J. A. (2013). Resident's attitudes towards tourism development in Cape Verde Island. Tourism Geographies, 15(4), 654-679. doi: 10.1080/14616688.2013.769022

40. Roxas, F. M., Rivera, J. P., \& Gutierrez, E. L. (2020). Mapping stakeholders' roles in governing sustainable tourism destinations. Journal of Hospitality and Tourism Management, 45, 387-398. doi: 10.1016/j.jhtm.2020.09.005

41. RTMCT (Republic of Turkey Ministry of Tourism and Culture). (2021). Turizm Tesisleri [Tourism Facilities]. Republic of Turkey Ministry of Tourism and Culture General Management of Investment and Enterprises. Retrieved January 23, 2021, from https://yigm.ktb.gov.tr/TR9579/turizm-tesisleri.html

42. Şanlıöz-Özgen, H. (2016). Sürdürülebilir turizm yönetiminde örgütlenme [Organization in sustainable tourism management]. In N. Koçak(Ed.), Sürdürülebilir Turiżm Yönetimi [Sustainable Tourism Management] (pp. 148-172). Ankara: Detay Publishing.

43. Spilanis, I., Tellier, J. L., \& Vayanni, H. (2012). Towards an observatory and a "quality label" for sustainable tourism in the Mediterranean. Valbonne: Plan Bleu. Retrieved from http://tourismobservatory.ba.aegean.gr/wp-content/uploads/2021/03/Blue-Plan-

Cahier12_destinations_EN_WEB.pdf

44. Sucheran, R. (2018). Barriers to environmental management in hotels in Kwazulu-Natal, South Africa. International Journal of Social Sciences, 3(3), 1352-1364. doi: 10.20319/pijss.2018.33.13521364

45. Swarbrooke, J. (1999). Sustainable Tourism Management. Oxon: CABI Publishing.

46. Tosun, C., \& Çalışkan, C. (2011). Profile of sustainability in Alanya (Turkey) as a tourist destination an analysis for achieving a better level of sustainable tourism development at local scale. Sophia Antipolis: Plan Bleu. Retrieved from https://fdocuments.in/reader/full/profile-ofsustainability-in-alanya-turkey-as-a-tourist-profile-of-sustainability

47. Travelife (2021). Travelife Accommodation Sustainability. Retrieved January 23, 2021, from http://www.travelifecollection.com/

48. UNEP \& WTO (United Nations Environment Programme and World Tourism Organization) (2005). Making Tourism More Sustainable A Guide for Policy Makers.

49. UNWTO (United Nations World Tourism Organization). (2013). Sustainable Tourism for Development Guidebook. Madrid: UNWTO. Retrieved from https://www.eunwto.org/doi/pdf/10.18111/9789284415496

50. UNWTO (United Nations World Tourism Organization) (2016). Tourism and the Sustainable Development Goals. Madrid: UNWTO. Retrieved from https://www.eunwto.org/doi/pdf/10.18111/9789284417254

51. UNWTO (United Nations World Tourism Organisation) (2019). UNWTO Guidelines for Institutional Strengthening of Destination Management Organizations (DMOs) - Preparing DMOs for new challenges. Madrid: UNWTO. doi: 10.18111/9789284420841 


\section{JOURNAL OF TOURISM AND SERVICES}

Issue 23, volume 12, ISSN 1804-5650 (Online)

www.jots.cz

52. Vodeb, K., Fabjan, D., \& Nižić, M. K. (2021). Residents' perceptions of tourism impacts and support for tourism development. Tourism and Hospitality Management, 27(1), 143-166. doi: $10.20867 /$ thm.27.1.10

53. Weaver, D. (2006). Sustainable Tourism: Theory and Practice. Oxford: Elsevier ButterworthHeinemann.

54. Weaver, D., \& Lawton, L. (2006). Tourism Management Third Edition. Australia: John Wiley \& Sons.

55. World Commission on Environment and Development (1987). Our Common Future. Oxford University Press.

56. WTTC (World Travel \& Tourism Council) (2020). Travel \& Tourism Global Economic Impact \& Trends 2020. World Travel \& Tourism Council. Retrieved from https://wttc.org/Research/Economic-Impact

57. Wut, T. M., Xu, B., \& Wong, H. S.-M. (2021). A 15-year review of "corporate social responsibility practices" research in the hospitality and tourism industry. Journal of Quality Assurance in Hospitality \& Tourism. doi: 10.1080/1528008X.2020.1864566

58. Yıldırım, A., \& Şimşek, H. (2013). Sosyal Bilimlerde Nitel Araştırma Yöntemleri 9. Basker [Qualitative Research Methods in Social Sciences 9th Edition]. Ankara: Seckin Publishing.

59. Zaiton, S., Syamsul, H., Kasimu, A., \& Hassan, H. (2016). Sustainable tourism practices among hotels in Malaysia: Financial and non-financial benefits. Journal of Sustainability Science and Management, 11(1), 73-81. Retrieved from http://jssm.umt.edu.my/wpcontent/uploads/sites/51/2016/06/6-web.pdf

\section{Brief description of Authors:}

\section{Res. Asst. Muhammet Necati Çelik}

ORCID ID: https://orcid.org/0000-0001-5201-8024

Affiliation: Department of Tourism Management, Graduate School, Alanya Alaaddin Keykubat University, Antalya, Turkey, www.alanya.edu.tr.

Email: muhammet.celik@alanya.edu.tr

Muhammet Necati Çelik is a Ph.D. candidate and a research assistant in the Tourism and Hotel Management Department at Alanya Alaaddin Keykubat University. He completed his Master's Thesis about the sustainability of accommodation enterprises in 2019. He focuses on sustainable tourism, sustainability of destination stakeholders, sustainable destination development, tourism impacts, and ecotourism in his researches.

\section{Asst. Prof. Aydın Çevirgen \\ Corresponding author \\ ORCID ID: https://orcid.org/0000-0002-3245-8783}

Affiliation: Department of Tourism Management, Faculty of Tourism, Alanya Alaaddin Keykubat University, Antalya, Turkey, www.alanya.edu.tr.

Email: aydin.cevirgen@alanya.edu.tr

Aydın Çevirgen is an assistant professor in the Department of Tourism Management, Faculty of Tourism at the Alanya Alaaddin Keykubat University. His research interests focus on community-based tourism, tourism management, sustainable tourism, ecotourism. 